\title{
Not planning a sustainable transport system - Swedish case studies
}

\author{
Göran Finnveden ${ }^{1, *}$, Jonas Åkerman ${ }^{1}$ \\ ${ }^{1}$ KTH Royal Institute of Technology , Sweden \\ *Corresponding author. Tel: +468 79073 18,E-mail:goran.finnveden@abe.kth.se
}

\begin{abstract}
The overall objective of the Swedish transport policy is to ensure the economically efficient and sustainable provision of transport services for people and business throughout the country. More specifically the transport sector shall contribute to the achievement of environmental quality objectives where the development of the transport system plays an important role in the achievement of the objectives. The aim of this study is to analyse if current transport planning supports this policy. This is done by analyzing two recent cases: the national infrastructure plan 2010-2021 and the planning of Bypass Stockholm, a major road investment. Our results show that the plans are in conflict with several of the environmental quality objectives. Another interesting aspect of the planning processes is that the long-term climate goals are not included in the planning processes, neither as a clear goal nor as factor which will influence the future transport system. In this way the long-term sustainability aspects are not present in the planning. We conclude that the two cases do not contribute to a sustainable transport system. Thus, several changes must be made in the processes, including putting up clear targets for emissions.
\end{abstract}

Keywords: Transport, Planning, Energy Use

\section{Introduction}

One of the pillars of the Swedish environmental policy is Environmental Policy Integration, suggesting that environmental factors must be integrated into all operational areas [1]. An expression for this is the sector responsibility for environmental issues that among other things entails that a number of agencies have responsibility to follow the environmental development within their sectors.

The overall objective of the Swedish transport policy is to ensure the economically efficient and sustainable provision of transport services for people and business throughout the country. More specifically the transport sector shall contribute to the achievement of the environmental quality objective Reduced climate impact and to other environmental quality objectives where the development of the transport system plays an important role in the achievement of the objectives. The objective Reduced climate impact requires significant reductions of greenhouse gases. In Sweden, the government's target is that emissions should decrease by $40 \%$, of which $2 / 3$ in Sweden, by 2020 compared to 1990 , and that the net emissions should be zero by 2050 [2]. These goals will require powerful economic instruments [2]. To be in line with the 2-degree target for climate change, the transport sector needs to reduce the emissions by $40 \%$ to 2020, $80 \%$ to 2030 and $95 \%$ to 2050, compared to 1990 according to the Swedish Road Administration [3].

The aim of this study is to analyse if current transport planning supports the Swedish transport policy and also to what extent environmental factors are integrated into the decision making processes.

\section{Methodology}

Two case studies were chosen for the analysis: The national infrastructure plan 2010-2021 and the planning of Bypass Stockholm, a major road investment which is also a part of the infrastructure plan. These plans are reviewed and analysed in relation to the transport policy goals and the integration of environmental aspects in the plans. As a criterion for a sustainable 
transport system we use in this paper the transport policy goal that the transport system shall contribute to a Reduced climate impact and other relevant environmental quality objectives. There are other criterion related to social and economic aspects of a sustainable transport system that could be added, but in this paper we focus on the ecological dimension.

\section{Results}

\subsection{Bypass Stockholm}

\subsubsection{Choice of alternatives}

The Swedish Road Administration has proposed in a statement to the Government that permission be granted for Bypass Stockholm [6]. It is interesting to study what alternatives were considered, and why Bypass Stockholm was recommended. In the Road Analysis [7], it is stated that the purpose of the road analysis is... to find the road corridor that best... ties together the north and south parts of the Stockholm County, creates a bypass for long distant traffic, improves the availability on the access roads, improves the possibilities for a common work and housing market for the region, allow a multi-nuclear region, and give possibilities for development in a region with growth. None of these goals touches on climate, environment, or sustainable development.

In the Road Analysis, three main alternatives are analysed:

- Bypass Stockholm without congestion charges

- Diagonal Ulvsunda without congestion charges. This is also a road alternative but located closer to Stockholm's inner-city than Bypass Stockholm.

- The Combination Alternative that includes congestion charges, public transport investments, and less road construction.

The Combination Alternative was developed by the Road Administration although it may not be the most competent organisation to develop that alternative since it is not responsible for public transport systems including railroads. The system for congestion charges included in the Combination Alternative is not the system that is used today. The structuring of the Combination Alternative has also met criticism [22] for having chosen expensive and inefficient investments in new tracks.

In the Road Analysis, the Combination Alternative is later rejected. The motivation is that it is not considered to meet the project goals. Here several key observations are possible. Already in the goal formulation it is set down that a road must be found. Other solutions for the foreseen transport problems are not of interest. In the Supplementary Report [6], it is stated also that "the Combination Alternative does not offer sufficient road capacity."

The main purpose of the Road Analysis was thus, according to the above, to find a road corridor. At the same time, there are the transport policy goals to adhere to. These entail that the transport system must both be effective from a socio-economic perspective and be longterm sustainable. In the Road Analysis, there is no direct evaluation made with regard to the transport policy goals, but several aspects of these are taken up. For example, environment and climate is evaluated for the alternatives and it is concluded that the Combination Alternative is better than the Bypass Stockholm. Also related to other goals such as safety, travel times and gender aspects, the Combination alternative is preferable [8].

A number of conclusions can be drawn from this discussion: 
- In the Road Analysis, the goal was to find a road corridor, not to find the best solution for Stockholm's traffic and transport problems. Thus, there is still a need to analyse alternative solutions for Stockholm's traffic problem.

- The Combination Alternative is rejected with reference to its not meeting the project goals. The choice of project goals is therefore central.

- None of the project goals in the Road Analysis is focused on environment, climate or sustainable development. If it had been so, then Bypass Stockholm could have been rejected with reference to its not meeting the project goals.

- Had the transport goals been guiding for the choice of alternatives, then Bypass Stockholm would hardly have been recommended [8].

\subsubsection{Traffic volumes}

New roads do not only lead to traffic moving from one road to another. New roads also generate new traffic [9-12]. There are several mechanisms for why new roads generate new traffic, and one can distinguish between effects in the short and long term. In the short term, new roads can lead to car-use being more attractive relative to other transport forms, and to travel itself becoming more attractive relative to alternative activities. In the long term, new roads can lead to new localisations. It can for example be attractive to develop new areas if there are better road connections, which then leads to increased traffic volumes.

The Swedish Road Administration's prognosis [6] includes short term effect on passenger vehicles. The traffic prognoses show that Bypass Stockholm leads to increased traffic volumes and decreased share of public transport. Increased traffic because of new localisation patterns is not included, however. For freight traffic, no consideration is made that new roads generate new traffic.

Thus, conclusions from this section are that:

- Bypass Stockholm leads to increased traffic volumes

- the Road Administration has likely underestimated these increases. This in turn imply that:

- congestion is underestimated

- travel times are underestimated

- accessibility is overestimated

- environment impact, including $\mathrm{CO}_{2}$ emissions, is underestimated

- effects of development of new areas on, for example, natural environments and emissions, are not considered fully

\subsubsection{Emissions of greenhouse gases}

According to the Swedish Road Administration [6], Bypass Stockholm will increase the emissions of greenhouse gases. In our estimation this increase is underestimated. An important reason is that Bypass Stockholm likely leads to higher traffic volumes than what the Road Administration has supposed (see above). Some additional reasons are discussed below.

A failure of earlier analyses of Bypass Stockholm [7] is that these did not include emissions from the construction of the road itself [13]. This was also one of the points that the Government Offices wanted to have supplementary information on [6].

The Road Administration has in the Supplementary Report [6] analysed energy consumption and emissions from construction of the road, but unfortunately in an incomplete way. The 
analysis that the Road Administration commissioned [14] includes energy consumption and greenhouse gas emissions for the road's construction, but not for the production of the materials. The construction of tunnels requires concrete and steel that are not included. An initial analysis indicates that the energy consumption for the production of these materials can be at least as large as the energy consumption that is already included in the analysis [8]. The effect on the calculations of emissions of $\mathrm{CO}_{2}$ can thereby be significant.

In connection with analyses of environmental impacts, it is sometimes discussed how one should assess energy use and its consequences. An example relates to emissions from electricity production. The different emissions from for example hydropower, nuclear power, wind power, and coal power vary tremendously of course. Thus a discussion often arises about what electricity production should be used in the analyses, e.g. [14-16]. There are two types of data that can be chosen: average data and marginal data. Average data relate to the average electricity production during a certain time period in a certain area, for example average production in Sweden in 2008. Marginal data relate to that specific electricity production that is changed, if electricity consumption increases or decreases. Identifying the marginal electricity source may be difficult [16] and may depend on the chosen time perspective and on what decisions future politicians make. It has therefore been suggested that sensitivity analysis should be made using both low-carbon and high-carbon electricity [23].

The choice of average data or marginal data depends to a large extent on the type of analysis and question one poses, e.g. [16-19]. If the analysis is to perform an environmental accounting of a system, then the average data for the system being studied is the most suitable. If instead the analysis is for assessing impacts of changes and measures that affect energy consumption, then marginal data are the most suitable choice.

What then is relevant in this context? Environmental impact assessment focuses on analysing the consequences of a decision. If a decision entails that energy consumption changes, data for the production that changes, not the average production, should be used. That is, marginal data should be used in environmental impact assessments. CBAs also focus on analysing effects of changes. The mathematical basis for analyses is differential equations. That is, even in this case, marginal data should be used rather than average data.

However, in the analysis that Stripple makes [14], average data are used as the primary alternative. This is questionable according to the above. Instead, marginal data should be used. That is also done by Stripple in a sensitivity analysis. There he uses coal condensation power as an example of marginal electricity production. The result then becomes radically different and the emissions of carbon dioxide from construction, maintenance and operation of the road become significantly higher. With average data the emissions are 0.248 million tons $\mathrm{CO}_{2}$ compared with 5.83 million tons when the figures for marginal electricity production are used [14].

In the Swedish Road Administration's Supplementary Report [6], a prognosis is used for future vehicles and their emissions of $\mathrm{CO}_{2}$ [20]. In the prognosis, it is assumed that the share for renewable fuels will be circa $20 \%$ in 2020. Furthermore, it is assumed that the share of plug-in hybrids among new car sales will be 45\% in 2020, and that the total share of plug-in hybrids will be about $10 \%$ that year. These assumptions are very optimistic,. The prognosis that the share of vehicles driven with renewable energy will be $20 \%$ in 2020 can be compared with the Swedish Government's target of 10\% renewable fuels in transport by 2020 . Furthermore, the prognosis for plug-in hybrids (circa 10\% in 2020) can be compared with the 
Swedish Energy Agency's prognosis of 85000 vehicles (all-electric and plug-in hybrids together), which corresponds to circa $1.5 \%$.

In the calculations of $\mathrm{CO}_{2}$ emissions, two simplifications are then made that cause underestimations. One is that all vehicles that can use alternative fuels are driven exclusively with these [20]. The other simplification is that only emissions during the operation of the vehicle are considered. Excluded, therefore, are the emissions during:

- production of renewable fuel (which can be significant)

- production of electricity (which can be significant)

- production of the vehicle itself (which is larger for electric cars and plug-in hybrids than for conventional vehicles)

This leads to clear underestimations of the $\mathrm{CO}_{2}$-emissions.

To summarise, by the Swedish Road Administration's own assessment [6], Bypass Stockholm leads to increased emissions of the greenhouse gas $\mathrm{CO}_{2}$. This increase is underestimated, for the following reasons:

- the increase of traffic volume is likely underestimated.

- the production of materials for the roads has not been included.

- marginal data for the emissions should have been used.

- the introduction of vehicles fuelled with electricity and renewables has been overestimated.

- it has been assumed that vehicles that can use alternative fuels will be driven exclusively with these.

- emissions from the production of fuels and electricity for the operation of vehicles, have been excluded.

- emissions from the manufacturing of vehicles have been excluded.

\subsubsection{Cost-benefit analyses}

In an earlier report [13], we have discussed the use of CBAs both from a general perspective and in previous analyses of Bypass Stockholm. The reflection built on earlier CBAs [21]. In the Swedish Road Administration's Supplementary Report [6], a new CBA is made. The conclusion is reached that the CBA of Bypass Stockholm yields a positive result. There are, however, a number of deficiencies and uncertainties in the calculation. One is the underestimation of the $\mathrm{CO}_{2}$-emissions as discussed above. Another is the zero value given to encroachment onto natural and cultural environments, some with national importance. Another important aspect is how the future developments are included. In the analysis, future powerful economic instruments that are required to reach the Reduced climate change objective are not included. It is likely that if such policy changes were included, the benefits of a new road would decrease. This is because powerful economic instruments would probably reduce traffic volumes and thus reduce benefits from time savings. In an earlier CBA [21] it was also showed that an increased oil prices would significantly reduce the benefits of a new road.

\subsection{National infrastructure plan}

The national infrastructure plan includes suggestions for new investments and maintenance for the Swedish transport system corresponding to approximately 50 billion euro. It was developed by the Swedish transport agencies and submitted to the government [4]. An environmental assessment of the plan was also submitted [5]. 
There are two overarching aspects of the Swedish transport policy, it should be economically efficient and it should support a sustainable provision of transport services. However, these two goals do not seem to have the same importance in the planning. In the plan, it is stated that the economic efficiency, measured by cost-benefit analyses, has been guiding the work [4]. The corresponding comment is not made regarding sustainable transport service. One reason for this may be the existence of established methods for evaluating the economic efficiency. For sustainability, corresponding tools are according to the plan lacking, and it is therefore difficult to evaluate [4].

The environmental assessment [5] concludes that the national infrastructure plan will

- lead to increased impacts on the biological diversity (which is relevant for the environmental quality objective A Rich Diversity of Plant and Animal Life),

- only in a limited way contribute to the achievement of the environmental quality objective Clean Air,

- not lead to a decreased number of people being affected by noise above reference values decided by the parliament and thus not contribute to a sustainable development with regards to human health and a good environment.

In relation to emissions of greenhouse gases, it is claimed that the plan will lead to small emission reductions $[4,5]$. It is thus clear that the planned projects do not contribute to the significantly decreased emissions that are required. Furthermore, the agencies have underestimated the energy use and greenhouse gas emissions in several ways. They have

- not at all, or only to a limited extent, included energy use and emissions from building of infrastructure.

- assumed large fractions of vehicles which can use renewable fuels or electricity.

- assumed that all vehicles that can use renewable fuels do that all the time.

- assumed zero emissions from production of renewable fuels.

- assumed low emissions from electricity when electricity use is increasing and high emissions when electricity use is decreasing.

- only partially included the increased transport volume caused by new infrastructure.

It is therefore likely that the plan instead will lead to increased emissions of greenhouse gases.

The plan was accompanied by an environmental assessment[5] in line with European directives [24]. It is however unclear to what extent the assessment has influenced the plan since it is noted in the assessment that the suggestions in the plan is in conflict with the environmental quality objectives and thus in conflict with the transport policy.

The environmental assessment also has some limitations in relation to the requirements formulated in the directive [24]. One such requirement is that the plan should be compared with a zero-alternative that is the likely development without the plan. The zero-development (as well as the plan) includes the so called EET-strategy, a strategy until 2020 for efficient energy and transport systems developed by several Swedish agencies. In the infrastructure plan it is however concluded that it is not likely that this strategy will be implemented. Thus the zero-alternative includes a non-likely development. Furthermore, no policy measures are assumed after 2020. Although it is clear that in order to reach the Reduced climate change goal, significant policy measures are required, no such measures are assumed in the plan. Thus the transport agencies either do not believe in the goals the Parliament has decided on, or the zero-alternative does not represent the likely development. This has implications for the comparisons between the plan and the zero alternative, and also for the cost-benefit analysis 
performed. Another requirement is that the environmental assessment should include also other reasonable alternatives. The proposed document did however only include an alternative with minor modifications.

\section{Conclusions}

The National Road Authority suggested the Bypass Stockholm in spite of this alternative being worse than other alternatives from a climate and environmental perspective and according to their own evaluation leading to increased emissions of greenhouse gases. Also the suggested infrastructure plans do not fulfill important environmental quality objectives. Since these two cases do not contribute to the fulfillment of relevant environmental quality objectives, we conclude that the two cases do not contribute to a sustainable transport system and are thus not in line with the transport policy objectives.

Another interesting aspect of the planning processes is that the long-term climate goals, or other sustainability issues, are not included in the planning processes, neither as a clear goal nor as factor which will influence the future transport system. In this way the long-term sustainability aspects are not present in the planning. Thus, several changes must be made in the processes. Examples of such changes are:

- When goals for projects and plans are formulated, environmental and sustainability aspects should be included.

- If environmental and sustainability project or policy goals are not met, new alternatives should be developed and analysed.

- Project goals should not define the solutions (as for example the goal to find a road corridor in the Bypass Stockholm case), but be open to different possibilities.

- Environmental assessments should be performed using state-of-the art methods and data.

- Long-term environmental and sustainability goals should be included in the planning as a factor that might influence the future transport system.

- Methods for assessing the sustainability of transport systems should be developed.

\section{References}

[1] Nilsson, M. and Eckerberg, K. (Eds.), Environmental Policy Integration in Practice. Shaping Institutions for Learning, Earthscan, 2007.

[2] Sweden Government Offices, En sammanhållen klimat- och energipolitik - klimat. Regeringens proposition 2008/09: 162. Regeringskansliet, 2009.

[3] Swedish Road Administration, Vägverkets handlingsplan för begränsad klimatpåverkan. Publikation 2009:82. Vägverket, 2009

[4] Swedish Road Administration, Nationell plan för transportsystemet 2010-2021. Vägverket, 2009

[5] Swedish Road Administration, Miljökonsekvensbeskrivning för Nationell plan för transportsystemet 2010-2021. Vägverket, 2009.

[6] Swedish Road Administration, Komplettering i tillåtlighetsärendet Förbifart Stockholm. Med bilagor. Vägverket, 2009.

[7] Swedish Road Administration, Nord-sydliga förbindelser i Stockholmsområdet. Vägutredning. Vägverket, 2005. 
[8] Finnveden, G. och Åkerman, J., Förbifart Stockholm, klimatet och miljön - en fallstudie inom vägplaneringen. TRITA-INFRA-FMS 2009:2. KTH, 2009.

[9] The Standing Advisory Committee on Trunk Road Assessment, Trunk Roads and the Generation of Traffic. The Department of Transport. London, HMSO, 1994.

[10] Goodwin, P.B., Empirical evidence on induced traffic. A review and synthesis. Transportation, 23, 1996, 35-54.

[11] European Conference of Ministers of Transport, Infrastructure-induced mobility. OECD, 1998.

[12] Noland, R.B. and Lem, L.L., A review of the evidence for induced travel and changes in transportation and environmental policy in the US and the UK. Transportation Research Part D, 7, 2002, 1-26.

[13]Finnveden, G. and Sterner, T., Reflektioner på samhällsekonomiska analyser i allmänhet och på kalkylen för nord-sydliga förbindelser i Stockholm i synnerhet. TRITAINFRAFMS- 2007:1. KTH, 2007.

[14] Stripple, H., Kompletterande underlag för tillåtlighetsprövning - en översiktlig miljöstudie av väginfrastrukturen i projekt Förbifart Stockholm. IVL Svenska Miljöinstitutet. 2009.

[15] Sköldberg, H. och Unger, T., Effekter av förändrad elanväning/elproduktion. Rapport 08 30. Elforsk, 2008

[16] Swedish Energy Agency, Koldioxidvärdering av energianvändning. Vad kan du göra för klimatet? Energimyndigheten, 2008.

[17]Ekvall, T., Weidema, B.P., System Boundaries and Input Data in Consequential Life Cycle Inventory Analysis. Int. J. LCA. 9, 2004, 161-171.

[18]Finnveden, G. and Moberg Å., Environmental systems analysis tools - an overview. $J$ Cleaner Production. 13, 2005, 1165-1173.

[19]Tillman, A.-M., Significance of decision-making for life-cycle assessment. Environmental Impact Assessment Review, 20, 2000, 113-123.

[20]WSP, Bilparksprognos i Åtgärdsplaneringen. EET-scenario och referensscenario. Rapport 200825. WSP Analys och Strategi, 2008..

[21]Transek, Samhällsekonomiska kalkyler för Nord-sydliga förbindelse i Stockholm. Rapport 2006:18. Transek, 2006.

[22] Swedish Society for Nature Conservation, Synpunkter från Naturskyddsföreningen i Stockholm län på kompletterande underlag inför en eventuell tillåtlighetsprövning enl 17 kapitel Miljöbalken av "Effektivare Nord-sydliga förbindelser i Stockholmsområdet". Naturskyddsföreningen i Stockholms län, 2009.

[23] Finnveden, $\mathrm{G}$, A World with $\mathrm{CO}_{2}$-caps. Electricity production in consequential assessments. Int J LCA, 13, 2008, 365-367.

[24]European Parliament and Council of the European Union, Directive 2001/42 on the assessment of the effects of certain plans and programmes on the Environment, Brussels. 